\title{
The Effects of Transient Temperature around Welds on Mechanical Properties of A36 Steel Plate
}

\author{
Moh. Jufri ${ }^{a}$, Alfin Aprilianto ${ }^{b}$, Nur Subeki ${ }^{\mathrm{c}}$ \\ ${ }^{a, b, c}$ Department of Mechanical Engineering, Engineering Faculty, \\ University of Muhammadiyah Malang \\ Jalan Tlogomas No. 246, Phone. (0341) 464318-128 Fax. (0341) 460782 Malang 65144 \\ Email: Jufri63@yahoo.com
}

\begin{abstract}
There are various ways for welding experts to improve their production quality, and one of which is by designing a particular type of welding tool. Besides aiming to replace the function of operator's body parts, the tool is also able to control buckling distortions, crack propagations, and stress voltage, as well as to save an additional work, which is the heat treatment after welding process. The best method to control buckling distortions from the thin plate is by applying pre-heating and thermal tensioning. Thermal tensioning is the characterization by heat application during welding process. Transient thermal tensioning is a supporting tool around the weld which is given periodical heat by following the movement of arc welding. The purpose of this research was to minimize distortions and maximize the performance (mechanical properties) of welding joints shaped due to the transient temperature application during the welding process.

The method employed in this research was experiment by using A36 steel plate with transient temperature variation of 100,200 , and $300^{\circ} \mathrm{C}$, with velocity of $8 \mathrm{~mm} / \mathrm{s}$ and heater (toutch) distance of 4,6 , and $8 \mathrm{~cm}$. In this research, the researcher conducted tensile-strength test according to the JIS G 3101 standard and hardness test around weld, HAZ (Heat Affected Zone), and parent metal.

The findings showed that the change of transient temperature and heater distance affected the mechanical properties (hardness and tensile strength) of A36 steel. The highest level of hardness was obtained in the temperature of $200^{\circ} \mathrm{C}$ and heater distance of $6 \mathrm{~cm}$, which was as much as $404 \mathrm{VHN}$. The highest level of tensile strength was obtained in the temperature of $200^{\circ} \mathrm{C}$ and heater distance variation of $8 \mathrm{~cm}$ with yield stress of $302 \mathrm{Mpa}$ and maximum tensile strength of as much as $491 \mathrm{Mpa}$.

Keywords: Pull; Temperature; Transient; Tensile
\end{abstract}

\section{INTRODUCTION}

The joining metal process by a welding system is more commonly applied nowadays, either in building construction, pipes installation, or mechanical construction due to the numerous advantages such as affordable cost, relatively quick completion, lighter result, and more varied construction shape [12] (Wiryosumarto, H. dan Okumura, $T, 2000)$. The weld strength is generally determined by the composition and electrode properties, welding process, direct-heating area, and residual stress. Electric welding 
tools and heat generator comes from electricity and gas. Thus, there are several factors that affect the welding result such as voltage, electric current, and heat input [7][9]. The voltage will affect heat input, which, in turn, affects the temperature distribution, so the metal around weld will undergo a thermal cycle. This definitely affects the micro structure shaped in the weld, heat-affected zone (HAZ), and base metal, which subsequently affects the mechanical properties, physical characteristics, and micro structures.

Besides micro-structure changes, voltage spike (residual stress) can also cause distortion. The residual stress and distortion significantly affect the structure design because they would cause voltage concentration and generate unexpected shape according to the design.

Residual distress and weld distortion can be reduced by: minimizing the heat input and welding length, minimizing the plate thickness, determining welding sequence, and so forth [2][3]. Welding distortion should be prevented at any cost because it can cause stress concentration and unexpected shape based on the design. The welding distortion can be controlled and minimized through component stressing, cutting optimalization and welding sequencing, heat input decreasing and transient thermal tensioning [13][8].

Transient heating is a method to control distortions, mechanical properties, micro structure, and welding residual distress by applying local heat around welding line during welding process. This research was conducted by applying transient temperature around weld before and after the welding process by adjusting the temperature gradient [13].

\section{Methodology}

This research applied experimental method. The materials used in this research were A36 low-carbon steel with E71T-1 electrode type and shielding gas (CO2).

The welding process employed FCAW welding tool with transient temperature variation of $100,200,300$, heater (toutch) distance of 4,6 , and $8 \mathrm{~cm}$ and welding velocity of $8 \mathrm{~mm} / \mathrm{s}$ operated automatically. The welding joint was one layer circuit with plate thickness of $5 \mathrm{~mm}$. The seam welding was made in the shape of double $V$ with the angle of $70^{\circ}$ as illustrated in Figure 2.1. The welded plate dimension was $120 \mathrm{~mm} \times 400$ $\mathrm{mm} \times 5 \mathrm{~mm}$. In this research, tensile strength testing was conducted according to the JIS G3101 standard [5] whereas the hardness testing was conducted around weld, HAZ, and parent metal (as illustrated in figure 2).

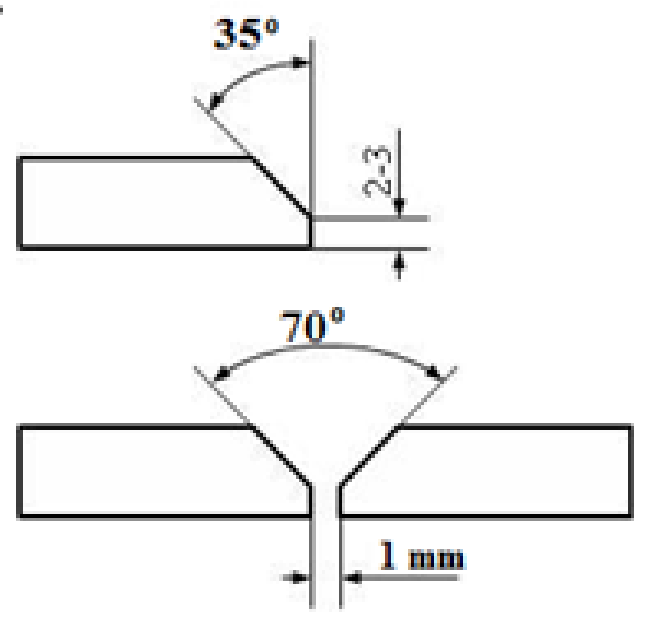

Figure 2.1 Seam But Join $70^{\circ}$ 


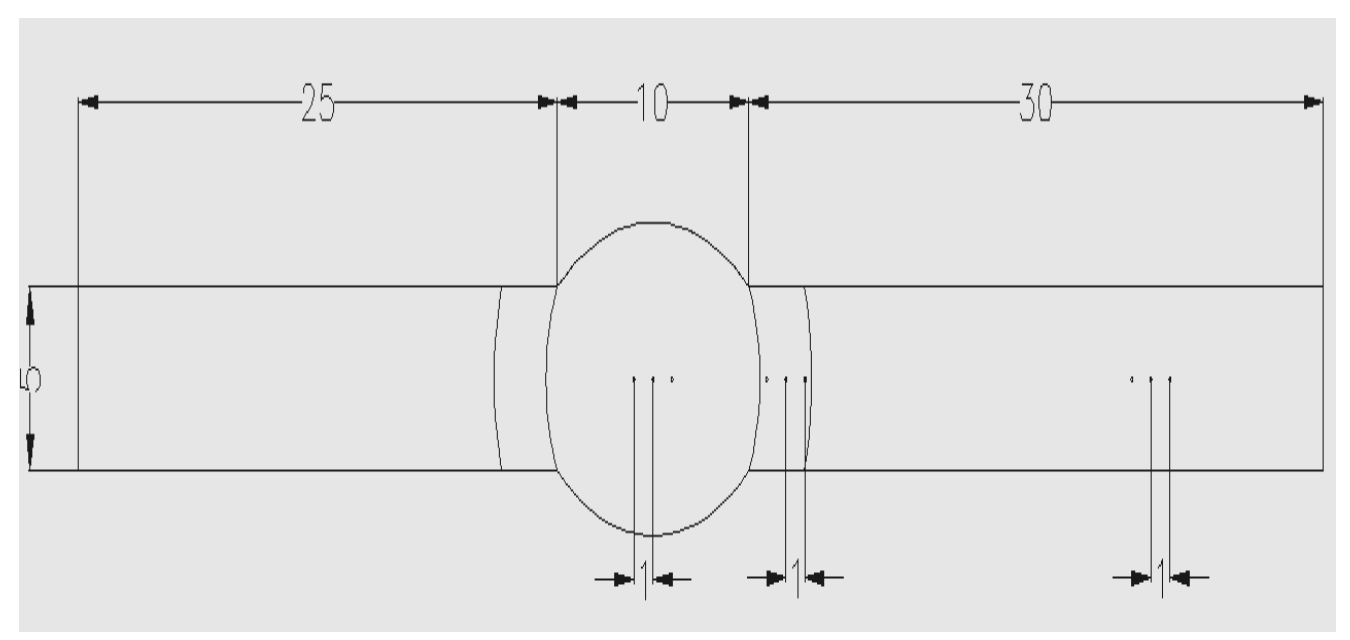

Figure 2.2 Hardness Sampling Spot

\section{Results and Analysis}

The figure below illustrates the result of hardness testing after the welding process with transient temperature variation of $100,200,300^{\circ} \mathrm{C}$ with the heater (toutch) distance of $4,6,8 \mathrm{~cm}$ from the weld and welding velocity of $8 \mathrm{~mm} / \mathrm{s}$ by applying Vickers Micro Hardness method.

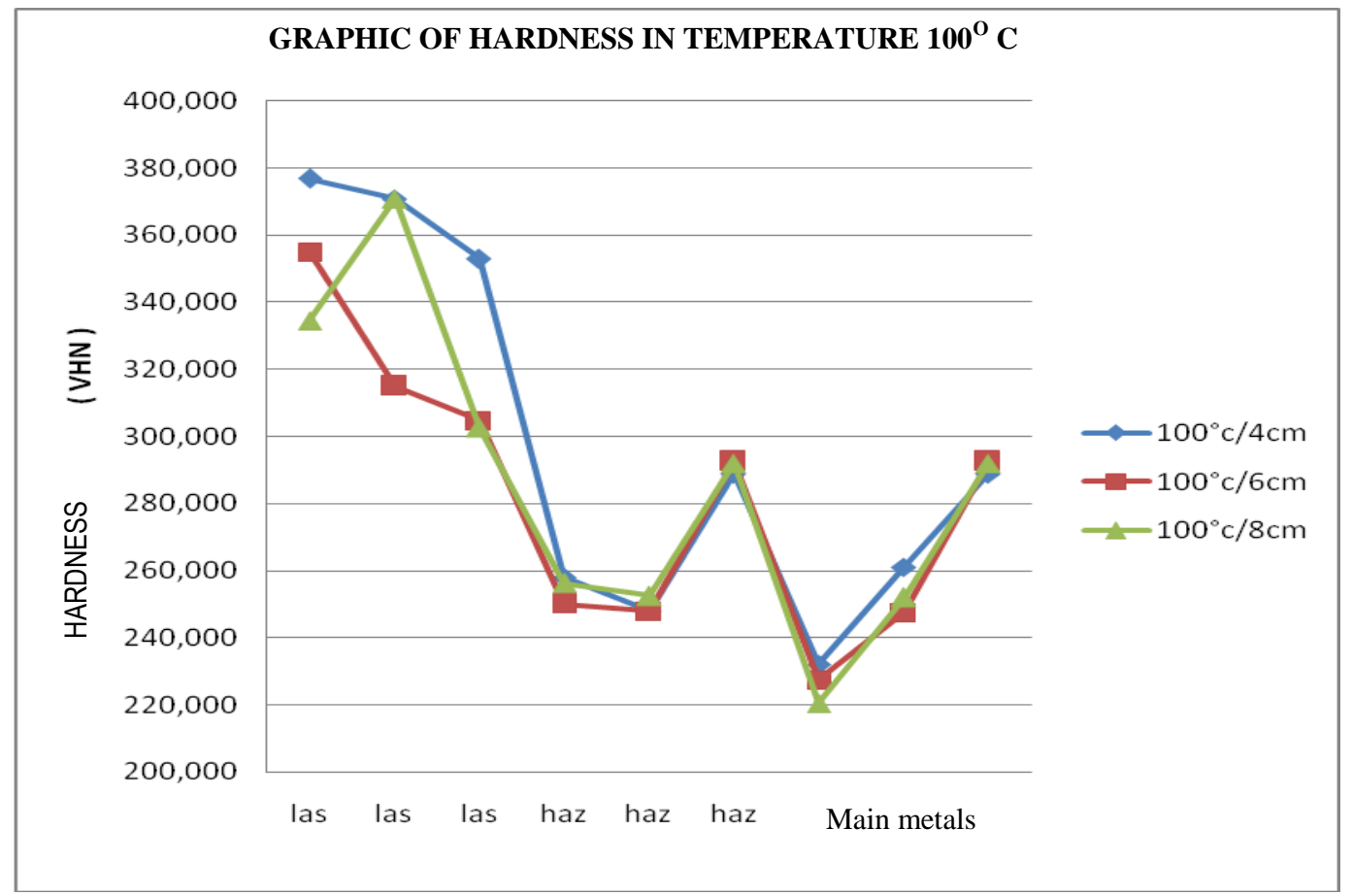

Figure 3.1 Hardness Testing Result in the temperature of $100^{\circ} \mathrm{C}$ and heater distance of $4,6,8 \mathrm{~cm}$. 


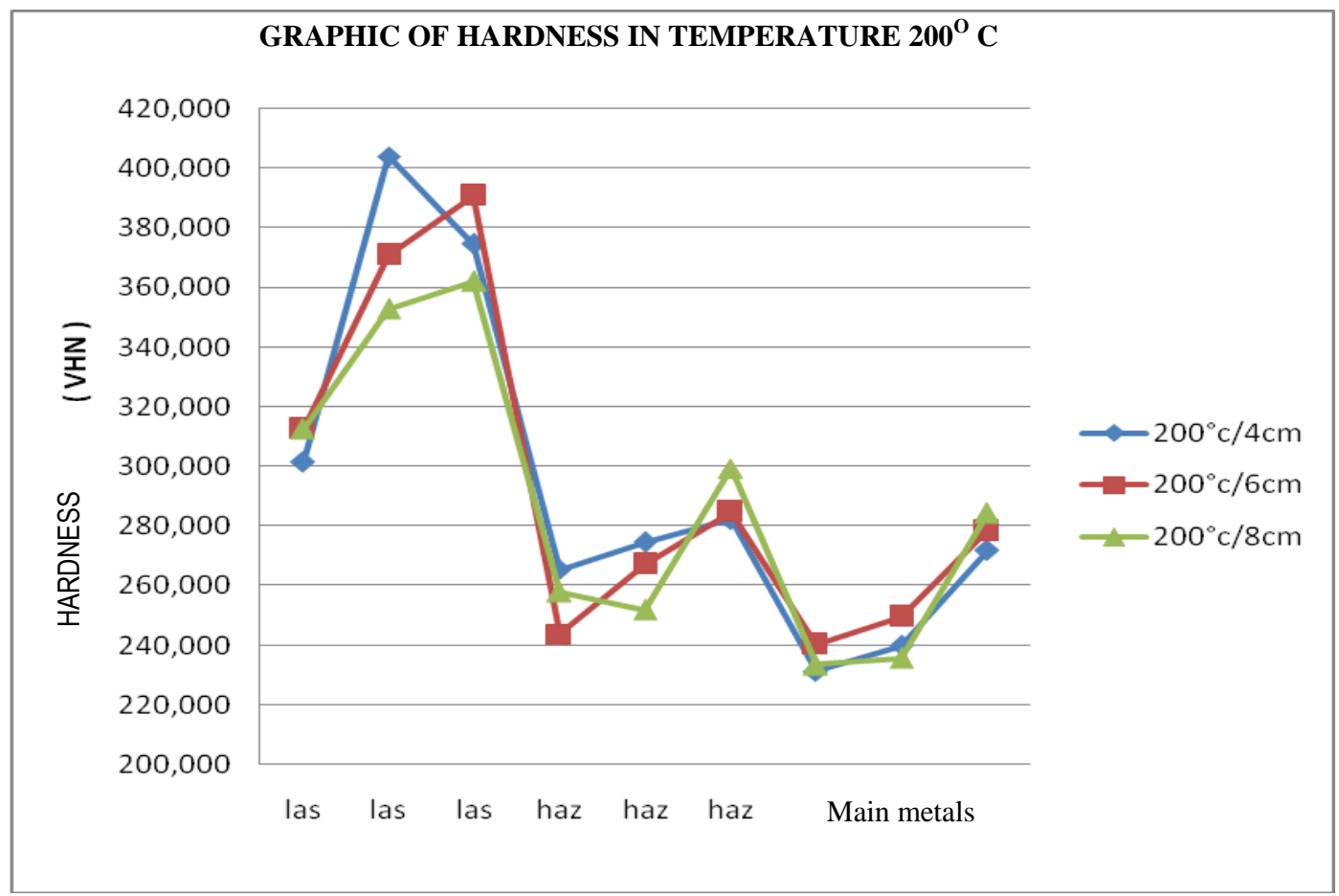

Figure 3.2 Hardness Testing Result in the temperature of $200^{\circ} \mathrm{C}$ and heater distance of $4,6,8 \mathrm{~cm}$.

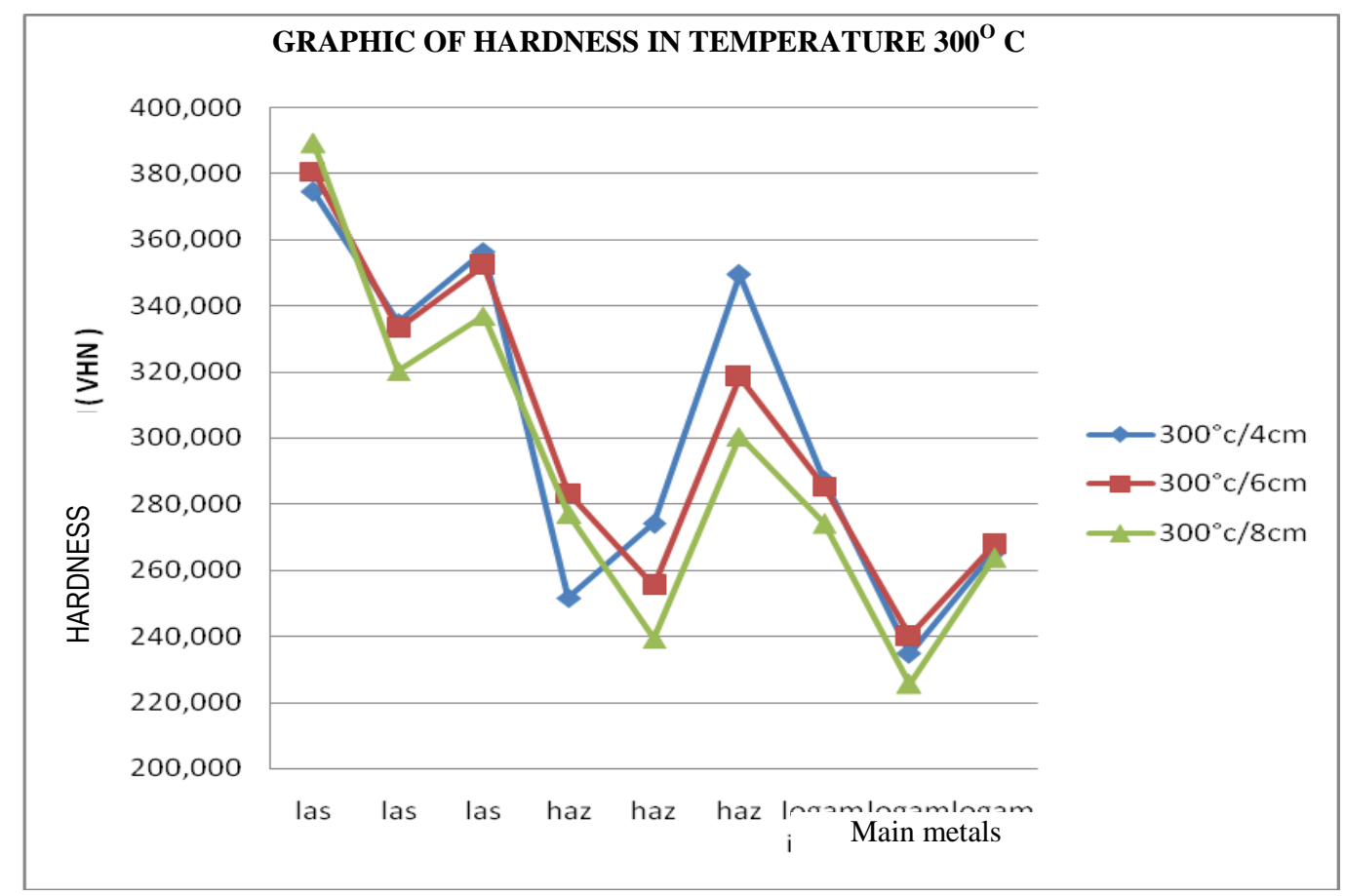

Figure 3.3 Hardness Testing Result in the temperature of $300^{\circ} \mathrm{C}$ and heater distance of $4,6,8 \mathrm{~cm}$. 


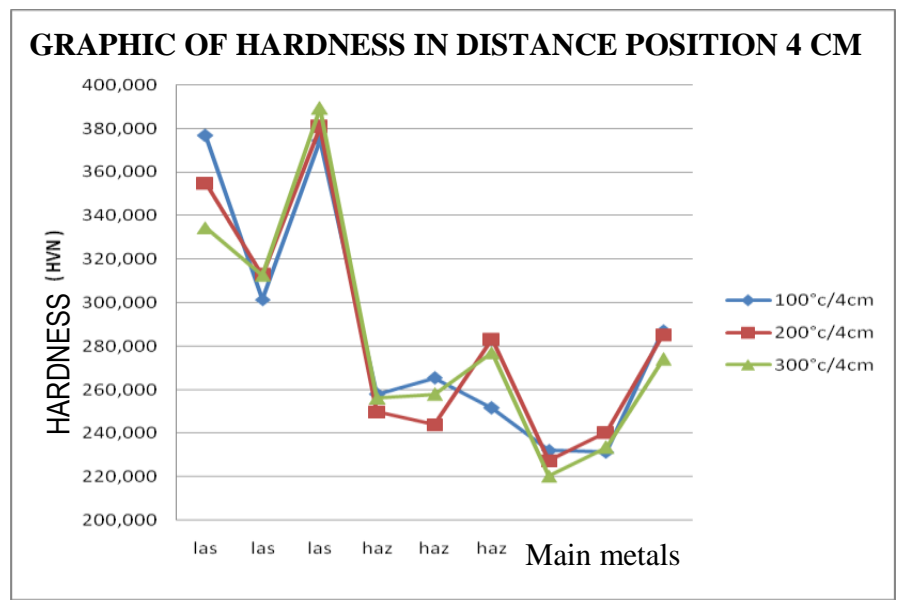

Figure 3.4 Hardness Specimen Testing Result in the hetaer distance of $4 \mathrm{~cm}$ and temperature variation of $100^{\circ} \mathrm{C}, 200^{\circ} \mathrm{C}, 300^{\circ} \mathrm{C}$.

Figure 3.1, 3.2, and 3.3 illustrate the hardness level on the transient temperature of 100,200 , and $300^{\circ} \mathrm{C}$ with heater distance of 4,6 , and $8 \mathrm{~cm}$. It was showed that the hardness level around the weld was higher than the one in HAZ and parent metal due to the change of micro structure in heat-affected zone during the welding. The hardness level on HAZ area was higher than the one in parent metal due to the same micro structure between grain boundaries ferrite, widmanstatent ferrite and the fine parts of HAZ. This was due to the abundance of ferrite and fine pearlite [11]. Meanwhile, in parent metal the hardness level decreased, yet in the second spot and the next, there was a significant increase although the hardness level was still lower than the one in HAZ area. The increase of hardness level on parent metal within the heater distance variation of 4 , 6 , and $8 \mathrm{~cm}$ was caused by the close distance between heater and parent metal, in which the structure was in ferrite and soft pearlite shape [4][10]. In this hardness testing, the testing distance was important to determine the hardness level of welding joint at particular spot. This was proven by the testing result that the hardness level slightly decreased from the center of welding metal [7][9]. In Figure 3.1, the hardness level tested on the temperature and heater distance variation of $100^{\circ} \mathrm{C} / 4 \mathrm{~cm}$ possessed the highest hardness level, and then respectively followed with the temperature and heater distance variation of $100^{\circ} \mathrm{C} / 6 \mathrm{~cm}$ and $100{ }^{\circ} \mathrm{C} / 8 \mathrm{~cm}$.

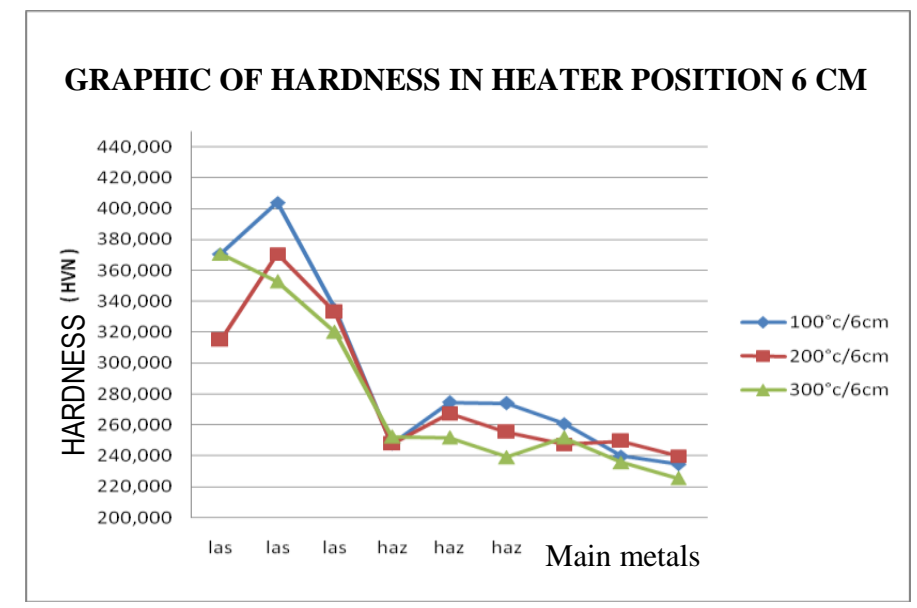

Figure 3.5 Hardness Specimen Testing Result on the hetaer distance of $6 \mathrm{~cm}$ and temperature variation of $100^{\circ} \mathrm{C}, 200^{\circ} \mathrm{C}, 300^{\circ} \mathrm{C}$. 
In Figure 3.2, the average hardness level on temperature and heater distance variation of $200^{\circ} \mathrm{C} / 4 \mathrm{~cm}$ possessed the highest hardness level, and then respectively followed with the temperature and heater distance variation of $200^{\circ} \mathrm{C} / 6 \mathrm{~cm}$ and $200{ }^{\circ} \mathrm{C} / 8 \mathrm{~cm}$. In Figure 3.3 , the average hardness level on temperature and heater distance variation of $300^{\circ} \mathrm{C} / 4 \mathrm{~cm}$ possessed the highest hardness level, and then followed with the temperature and heater distance variation of $300^{\circ} \mathrm{C} / 6 \mathrm{~cm}$ and $300^{\circ} \mathrm{C} / 8 \mathrm{~cm}$.

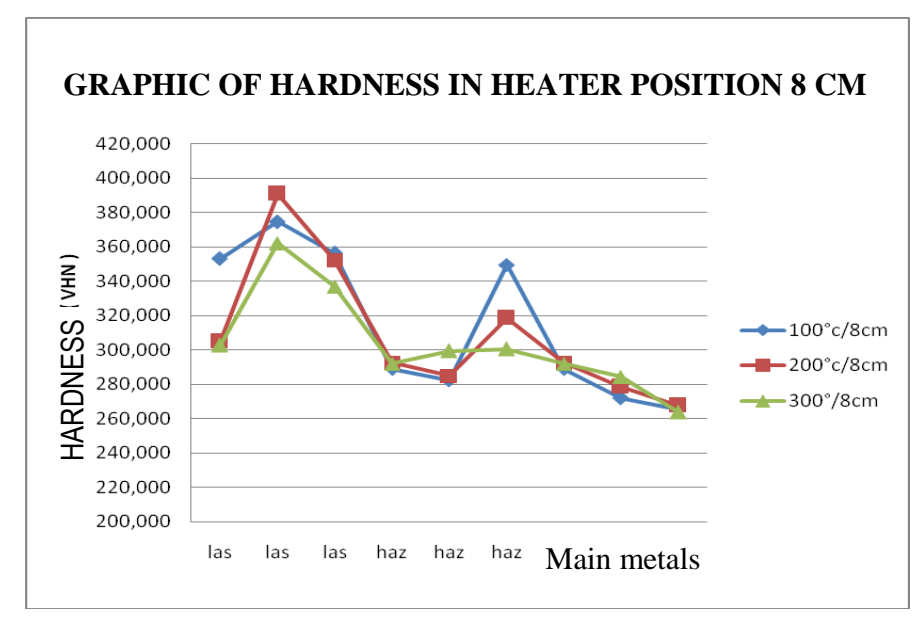

Figure 3.6 Hardness Specimen Testing Result on the hetaer distance of $8 \mathrm{~cm}$ and temperature variation of $100^{\circ} \mathrm{C}, 200^{\circ} \mathrm{C}, 300^{\circ} \mathrm{C}$.

Figure 3.4, 3.5, and 3.6 illustrate the hardness level on heater distance of 4,6 , and 8 $\mathrm{cm}$ with transient temperature of 100,200 , and $300^{\circ} \mathrm{C}$. It was showed that the decrease on the hardness level around weld happened due to the heat received during the welding that changed the micro structure formation. The hardness level on HAZ area was higher than the one on parent metal due to the similar micro structure, which was between grain boundaries ferrite, widmanstatent ferrite and the fine parts of HAZ. This happened due to the abundance of ferrite and fine pearlite [11]. Meanwhile, in parent metal the hardness decreased, yet in the second spot and the next, there was a significant increase on the hardness level on heater temperature variation of $100^{\circ} \mathrm{C}, 200^{\circ} \mathrm{C}$, and $300^{\circ} \mathrm{C}$. This was due to the temperature and close heater distance to the parent metal. It can be concluded that the parent metal possessed prevalent hardness level as well as the lowest among other areas due to the ferrite and soft pearlite shape of micro structure [4][10]. In the hardness level testing, the testing distance was important to recognize the joint hardness level at particular spots. This was proven by the testing result, which showed that the hardness level slightly decrease from the weld center [7][9]. Figure 5 shows that the average hardness level on the temperature and heater distance of $300^{\circ} \mathrm{C} / 4 \mathrm{~cm}$ reached the highest point, and was followed by the temperature and heater distance of $100^{\circ} \mathrm{C} / 4$ $\mathrm{cm}$ and $200^{\circ} \mathrm{C} / 4 \mathrm{~cm}$ respectively. Meanwhile, figure 6 shows that the average hardness level on the temperature and heater distance variation of $200^{\circ} \mathrm{C} / 6 \mathrm{~cm}$ reached the highest point, and was followed by temperature and heater distance variation of $100^{\circ} \mathrm{C} / 6 \mathrm{~cm}$ and $300{ }^{\circ} \mathrm{C} / 6 \mathrm{~cm}$ respectively. Figure 7 shows that the average hardness level on the temperature and heater distance of $200^{\circ} \mathrm{C} / 8 \mathrm{~cm}$ reached the highest point, and was followed by the temperature and heater distance of $100^{\circ} \mathrm{C} / 8 \mathrm{~cm}$ and $300^{\circ} \mathrm{C} / 8 \mathrm{~cm}$. These findings were in accordance with the research [4] which states that the higher the heater temperature, the lower the hardness level would be.

From the data of tensile strength testing, the graphics of maximum tensile strength and yield strength of carbon A 36 steel with temperature variation of $100^{\circ} \mathrm{C}, 200^{\circ} \mathrm{C}$, $300^{\circ} \mathrm{C}$ and heater distance variation 4,6 , and $8 \mathrm{~cm}$ can be obtained. The graphics are as follows: 


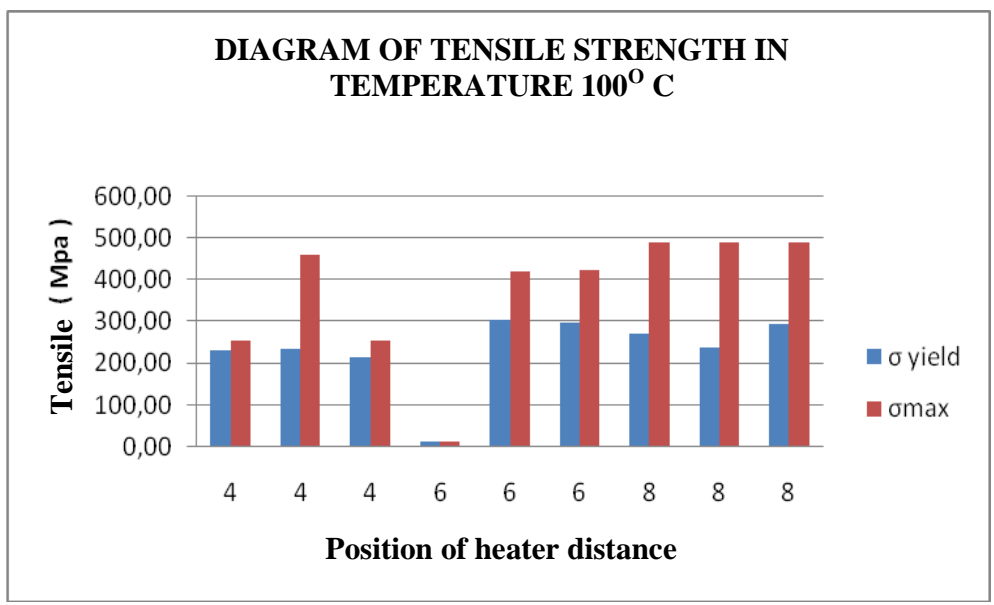

Figure 3.7 Tensile Strength Specimen Testing Result on the temperature of $100^{\circ} \mathrm{C}$ with heater distance variation of $4,6,8 \mathrm{~cm}$

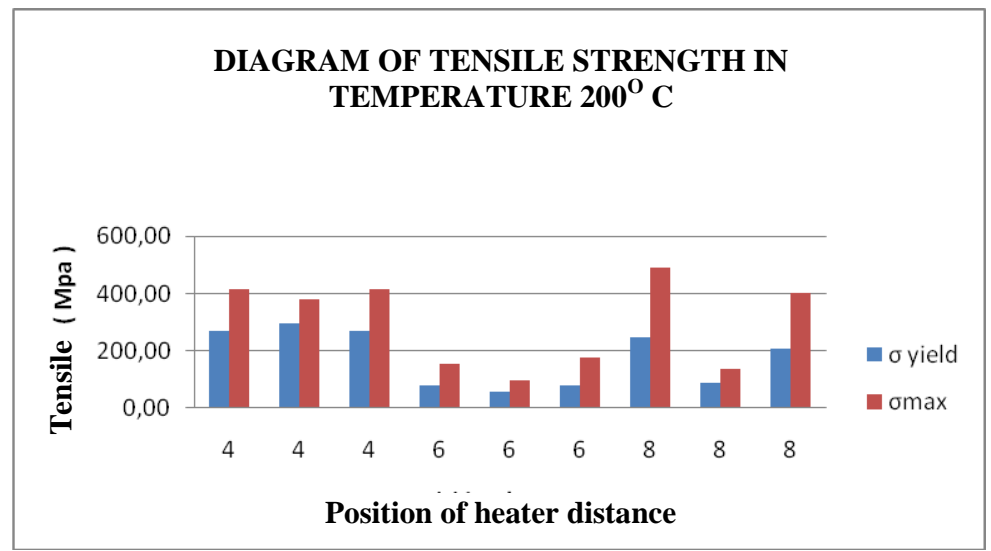

Figure 3.8 Tensile Strength Specimen Testing Result on the temperature of $200^{\circ} \mathrm{C}$ with heater distance variation of $4,6,8 \mathrm{~cm}$

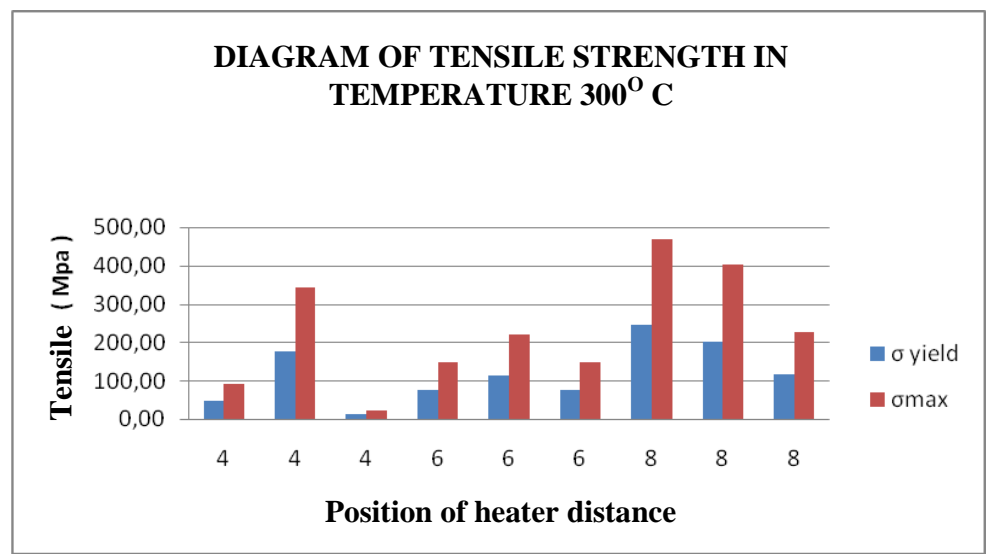

Figure 3.9 Tensile Strength Specimen Testing Result on the temperature of $300^{\circ} \mathrm{C}$ with heater distance variation of $4,6,8 \mathrm{~cm}$

Figure 3.7 illustrates the tensile strength value at $100^{\circ} \mathrm{C}$. The testing was conducted three times using different test specimen and heater distance of 4,6 , and $8 \mathrm{~cm}$. The 
tensile strength at temperature of $100^{\circ} \mathrm{C}$ and heater distance of $4 \mathrm{~cm}$ was as much as 234.67 Mpa (yield strength) and 458.24 Mpa (maximum tensile strength). Meanwhile, at the distance of $6 \mathrm{~cm}$ before the heater, the yield strength was $302.25 \mathrm{Mpa}$ and the maximum tensile strength was $422.28 \mathrm{Mpa}$. At $8 \mathrm{~cm}$ before the heater, the yield strength was 293.62 Mpa and the maximum tensile strength was $488.58 \mathrm{Mpa}$. From these findings, the researcher was able to compare the highest tensile strength level at the distance of $8 \mathrm{~cm}$ before the heater, which can increase the tensile strength. This increase happened due to the precipitation during welding process. Within the distance of $8 \mathrm{~cm}$, the heat affected zone insignificantly affected the grain boundaries, and the tensile strength will be more likely the same [1][7][9]. Figure 3.8 illustrated the tensile strength at the temperature of $100^{\circ} \mathrm{C}$. The testing was conducted three times using different test specimen and heater distance of 4,6 , and $8 \mathrm{~cm}$. The tensile strength at the temperature of $200^{\circ} \mathrm{C}$ and heater distance of $4 \mathrm{~cm}$ was $270.09 \mathrm{Mpa}$ for the yield stress and 416.16 Mpa for the maximum tensile strength whereas at the distance of $6 \mathrm{~cm}$, the yield strength was $81.57 \mathrm{Mpa}$ and the the maximum tensile strength was $177.10 \mathrm{Mpa}$.

Meanwhile, at the distance of $8 \mathrm{~cm}$ before the heater, the yield strength was 247.62 $\mathrm{Mpa}$ and the maximum tensile strength was $491.50 \mathrm{Mpa}$. From these findings, it can be compared the highest level of tensile strength generated at the distance of $8 \mathrm{~cm}$. This increase of strength happened due to the precipitation during welding process at $8 \mathrm{~cm}$ before the heater. At this point, the heat affected zone insignificantly affected the boundary grain, which made the tensile strength relatively up and down or similar [1][7][9]. Figure 3.9 illustrated the tensile strength at the temperature of $100^{\circ} \mathrm{C}$. The testing was conducted three times using different test specimen and heater distance of 4 , 6 , and $8 \mathrm{~cm}$. The tensile strength at the temperature of $100^{\circ} \mathrm{C}$ and heater distance of 4 $\mathrm{cm}$ was $177.61 \mathrm{Mpa}$ for the yield strength and $342.44 \mathrm{Mpa}$ for the maximum tensile strength. At $6 \mathrm{~cm}$ before the heater, the yield strength was $111.84 \mathrm{Mpa}$ and the maximum tensile strength was $219.51 \mathrm{Mpa}$. Meanwhile, at $8 \mathrm{~cm}$ before the heater, the yield strength was $245.39 \mathrm{Mpa}$ and the maximum tensile strength was $468.96 \mathrm{Mpa}$. From these findings, it can be compared the highest level of tensile strength generated at the distance of $8 \mathrm{~cm}$. This increase of strength happened due to the precipitation during welding process at $8 \mathrm{~cm}$ before the heater. At this point, the heat affected zone insignificantly affected the boundary grain, which made the tensile strength relatively up and down or similar (Nur Subeki 2009).

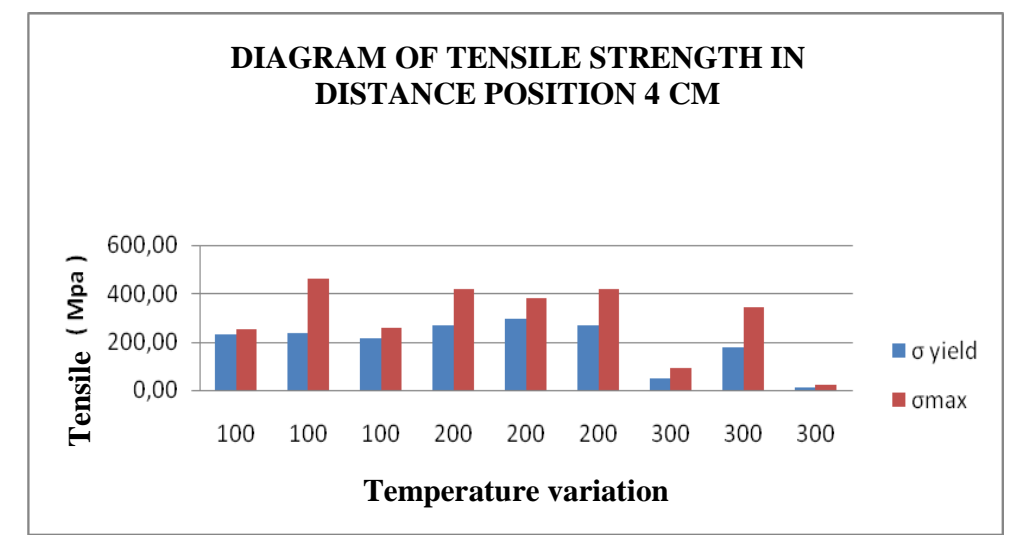

Figure 3.10 Tensile Strength Specimen Testing Result at heater distance of $4 \mathrm{~cm}$ and temperature variation of $100^{\circ} \mathrm{C}, 200^{\circ} \mathrm{C}, 300^{\circ} \mathrm{C}$ 


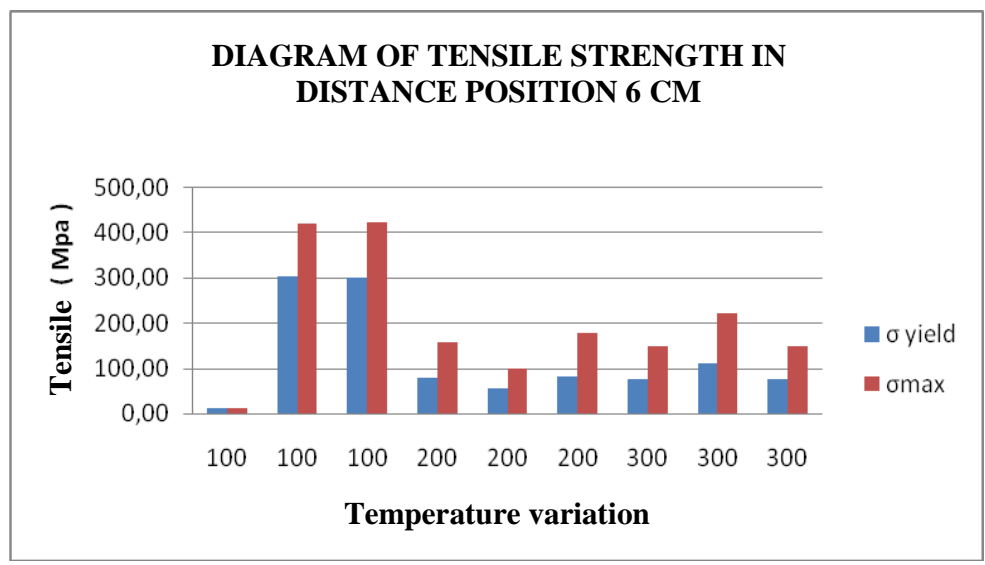

Figure 3.11 Tensile Strength Specimen Testing Result at heater distance of $6 \mathrm{~cm}$ and temperature variation of $100^{\circ} \mathrm{C}, 200^{\circ} \mathrm{C}, 300^{\circ} \mathrm{C}$

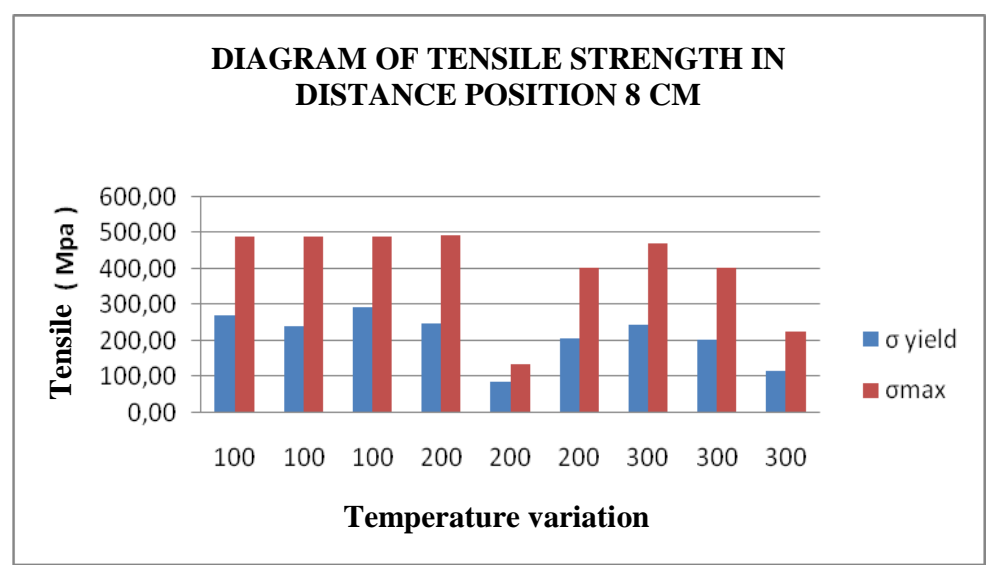

Figure 3.12 Tensile Strength Specimen Testing Result at heater distance of $8 \mathrm{~cm}$ and temperature variation of $100^{\circ} \mathrm{C}, 200^{\circ} \mathrm{C}, 300^{\circ} \mathrm{C}$

Figure 3.10 illustrated the tensile strength at the heater distance of $4 \mathrm{~cm}$. The testing was conducted three times using different test specimen and the temperature of $100^{\circ} \mathrm{C}$. The tensile strength at this condition was 234.67 Mpa for the yield strength and 458.24 Mpa for the maximum tensile strength. At the temperature of $200^{\circ} \mathrm{C}$, the yield strength was $270.09 \mathrm{Mpa}$ and the maximum tensile strength was $416.16 \mathrm{Mpa}$. Meanwhile, at the temperature of $300^{\circ} \mathrm{C}$, the yield strength was $177.61 \mathrm{Mpa}$ and the maximum tensile strength was $342.44 \mathrm{Mpa}$. From these findings, it can be compared the highest level of tensile strength generated at the temperature of $100^{\circ} \mathrm{C}$.

The conclusion shows that the decrease of tensile strength and force was due to the increasing temperature, which means that the tensile strength was inversely proportional to the temperature. Thus, if the material (steel) was applied higher temperature, the material strength will decrease. From this phenomenon, it can be concluded that the material ductility wil be higher if the temperature increases [1][13]. Figure 3.11 illustrated the tensile strength at the heater distance of $6 \mathrm{~cm}$. The testing was conducted three times using different test specimen and the temperature of $100^{\circ} \mathrm{C}$. The tensile strength at this condition was $298.20 \mathrm{Mpa}$ for the yield strength and $422.28 \mathrm{Mpa}$ for the maximum tensile strength. At the temperature of $200^{\circ} \mathrm{C}$, the yield strength was $81.57 \mathrm{Mpa}$ and the maximum tensile strength was $177.10 \mathrm{Mpa}$.

Meanwhile, at the temperature of $300^{\circ} \mathrm{C}$, the yield strength was $111.84 \mathrm{Mpa}$ and the maximum tensile strength was $219.51 \mathrm{Mpa}$. From these findings, it can be compared the highest level of tensile strength generated at the temperature of $100^{\circ} \mathrm{C}$. The conclusion 
shows that the decrease of tensile strength and force was due to the increasing temperature, which means that the tensile strength was inversely proportional to the temperature. Thus, if the material (steel) was applied higher temperature, the material strength will decrease. From this phenomenon, it can be concluded that the material ductility wil be higher if the temperature increases [1][13].

Figure 3.12 illustrated the tensile strength at the heater distance of $8 \mathrm{~cm}$. The testing was conducted three times using different test specimen and the temperature of $100^{\circ} \mathrm{C}$. The tensile strength at this condition was $238.99 \mathrm{Mpa}$ for the yield strength and 488.58 Mpa for the maximum tensile strength. At the temperature of $200^{\circ} \mathrm{C}$, the yield strength was 247.62 Mpa and the maximum tensile strength was $491.50 \mathrm{Mpa}$. Meanwhile, at the temperature of $300^{\circ} \mathrm{C}$, the yield strength was $245.39 \mathrm{Mpa}$ and the maximum tensile strength was $468.96 \mathrm{Mpa}$. From these findings, it can be compared the highest level of tensile strength generated at the temperature of $100^{\circ} \mathrm{C}$. The conclusion shows that the decrease of tensile strength and force was due to the increasing temperature, which means that the tensile strength was inversely proportional to the temperature. Thus, if the material (steel) was applied higher temperature, the material strength will decrease. From this phenomenon, it can be concluded that the material ductility wil be higher if the temperature increases [1][13].

\section{Conclusion}

1. The change of transient temperature and heater distance affected the mechanical properties (hardness level and tensile strength) of A36 steel.

2. The highest hardness level was generated on the temperature of $200^{\circ} \mathrm{C}$ and heater distance of $6 \mathrm{~cm}$, which was as much as $404 \mathrm{VHN}$.

3. The highest tensile strength was generated on the temperature of $200^{\circ} \mathrm{C}$ and heater distance variation of $8 \mathrm{~cm}$, with yield strength value of $302 \mathrm{Mpa}$ and maximum tensile strength of $491 \mathrm{Mpa}$.

\section{REFERENCES}

[1] Asfarizal. Pengaruh Masukan Panas Yang Ditinggikan Terhadap Kekuatan Tarik Baja Karbon Rendah, Jurnal Teknik. April 2008; No. 29 Vol. 2.

[2] Burak, Ya. I., Besedina, L.P., Romanchuk, Ya.P., Kazimirov, A.A. and Morgan, V.P., 1977, Controling the longitudional Plastic Shrinkage Of Metal During Welding, Avt. Svarka.

[3] Burak, Ya.l., Besedina, L.p., Romancuk, Ya.P., Kazimirov, A.A. and Morgan, V.P.,1979, selection of the Optimum Fields for Preheating Plates Before Welding , Avt. Svarka.

[4] Gathot, Dwi. Nur, H., Budi, LS., Abdillah, GB. Pengaruh variasi suhu preheat terhadap sifat mekanik material SA 516 Grade 7 yang disambung dengan metode pengelasan SMAW. Proceeding seminar Nasional sains dan teknologi terapan III. 2015.

[5] JIS. Non Ferrous Metal. Japan; 1973.

[6] Kenyon, W.1979. Dasar - Dasar Pengelasan. Ginting Dines. Jakarta: Erlangga.

[7] Subeki, Nur. Optimalisasi Komposisi Kandungan Mn Pada Filler Untuk Mendapatkan Ketangguhan Dan Kekerasan. 2011.

[8] Radaj, D. Heat effects of Welding: Temperature Field, Residual Stress, Distortion, Springer-Verlag. Berlin.1992.

[9] Subeki, Nur. Optimalisasi Penggunaan Heat Input pada Pengelasan Pipa Spiral untuk Meningkatkan kualitas Sambungan. Jurnal Teknik Industri. Agustus 2009; Vol. 10 Nomor 2: Hal 141-147. 
[10] Suharto. Teknologi pengelasan logam. Jakarta. PT. Rineka Cipta. 1991.

[11] Weldy, Sonaria, Winarko. Stress Relief Annealing Untuk Uji Kekerasan Dan Mikrostruktur Pada Hasil Pengelasan (SAW) Pipa Baja Api 5I-X65. 2011.

[12] Okumura. 2000. Teknologi pengelasan logam. Wiryosumarto. Jakarta: PT. Pradya Paramita.

[13] Wijoyo. Minimisasi Distorsi Sambungan Las Dengan Pemberian Flame Heating Selama Proses Pengelasan. Seminar Nasional Sains dan Teknologi Ke - 2. 2011. 